\title{
Seasonal Incidence of Major Insect Pests of Cowpea in Relation to Biotic and Abiotic Factors
}

\section{Maya Shree Mahipal ${ }^{1}$, Shri Gajendra Chandrakar ${ }^{1}$, Yashpal Singh Nirala ${ }^{1}$, Devendra Nishad ${ }^{2}$ and Birendra Tigga ${ }^{3}$}

\author{
${ }^{1}$ Department of Entomology, ${ }^{2}$ Department of Pathology, ${ }^{3}$ Department of Agronomy, \\ Indira Gandhi Krishi Vishwavidyalaya, Raipur- 492012, Chhattisgarh, India \\ *Corresponding author
}

\section{A B S T R A C T}

The present study was conducted at Horticultural Research Farm, College of Agriculture, Indira Gandhi KrishiVishwavidyalaya; Raipur (C.G.) during kharif season 2015-16. The

\begin{tabular}{|c|c|}
\hline Keywords & $\begin{array}{l}\text { results of field experiments revealed that the major insect pest viz., spotted pod borer, } \\
\text { flower thrips, pod sucking bug and green stink bug were attacking in cowpea germplasm }\end{array}$ \\
\hline $\begin{array}{l}\text { Cowpea, Flower } \\
\text { thrips, Biotic } \\
\text { and abiotic } \\
\text { factors. }\end{array}$ & $\begin{array}{l}\text { Lola. The incidence of pod sucking bug, green stink bug and flower thrips started from } \\
\text { third week after transplanting, further increased and recorded the peak activity of } 9.0 \text { bugs } \\
\text { per plant and } 12.3 \text { bugs per plant during second week of November, whereas the peak } \\
\text { activity of } 4.3 \text { thrips per plant was observed during first week of October. The cowpea }\end{array}$ \\
\hline Article Info & gradually with peak pod infestation of 19.7 per cent during third week of October. The \\
\hline $\begin{array}{l}\text { Accepted: } \\
\text { 19 June } 2017 \\
\text { Available Online: } \\
10 \text { August } 2017\end{array}$ & $\begin{array}{l}\text { correlated with maximum and minimum temperature while negatively correlated with } \\
\text { spotted pod borer infestation showed positive and non significant correlation with }\end{array}$ \\
\hline & $\begin{array}{l}\text { maximum and minımum temperature, rainfall, sunsnine nours, maximum and minimum } \\
\text { relative humidity. }\end{array}$ \\
\hline
\end{tabular}

\section{Introduction}

Cowpea is a tropical, annual herbaceous legume, which belongs to the family Papilionaceae (Fabaceae), order Leguminosae and genus Vigna. The cowpea is considered a grain legume or pulse (Uwaegbute, 1991). The cowpea grain contains an average of 23$25 \%$ protein and $50-67 \%$ carbohydrates (Singh et al., 1997). It has fat content of $1.3 \%$, fibre content of $1.8 \%$ and $8-9 \%$ of water. The most damaging pests of cowpea include those that occur during the flowering and podding stages. These pests include flower thrips, such as Megalurothrips sjostedti (Trybom) (Thysanoptera: Thripidae), pod borer, Marucavitrata (Fabricius) (Lepidoptera: Crambidae) and pod suckers such as, Riptortus dentipes (Hemiptera: Coreidae) (Adati et al., 2007). Many morphological and biochemical factors are known to be associated with insect resistance in crop plants. It is obvious in many cases that the morphological factors are more important in conferring non-preference and antibiosis. Some biochemical constituents may act as 
feeding stimuli for insects. Occurrence at lower concentration or total absence of such biochemical leads to insect resistance.

\section{Materials and Methods}

The seasonal incidence of cowpea insect pest, were recorded weekly on cowpea genotypes. Weekly observations on major insect pest population available in the experimental field were recorded on randomly selected five plants from experimental plots during the whole cropping season i.e. from September 2015 to December 2015. The method modified as according to (Jackai, 1982; Kumar and Kumar, 2015). Correlation analysis was worked out as per method given by Gomez and Gomez (1984).

\section{Results and Discussion}

\section{Seasonal activity of cowpea flower thrips (M. sjoestdi Trybom)}

Periodical observations on the flower thrips incidence showed that the first appearance of nymph and adult thrips population was started from $5^{\text {th }}$ week of September $\left(39^{\text {th }}\right.$ SMW (standard meteorological week)). Initially, there were 3.1 thrips per plant which increased up to the maximum 4.3 nymphs and adult per plant during the first week of October $\left(40^{\text {th }}\right.$ SMW). Thereafter, the nymph and adult population gradually declined to 1.5 thrips per plant during the third week of December (50th SMW). The thrips population was observed during the entire crop growth period, during this period maximum $\left(32.5{ }^{\circ} \mathrm{C}\right)$ and minimum temperature $\left(24.6{ }^{0} \mathrm{C}\right)$, morning $92 \%$ and evening relative humidity $57 \%$ and sunshine 7.7 hours/day prevailed (Tables 1 and 2; Fig. 1).

These finding are in conformity with Kumar et al., (2015) reported that Thrips (Megalurothripssjostedti Tryb.) population was observed in last week of September and its highest population was recorded in third week of October (5.87/flower bud). On the contrary, According to Patel et al., (2010) population of thrips was recorded in the month of March only and reached to its maximum level during fourth week of March. The thrips was noticed at flowering stage with varying population density. Singh and Singh (2014) also maximum and minimum thrips populations (2.53 and 0.15 insect/flower) were observed during 25th and 21st standard weeks respectively during zaid, 2009-10.

\section{Correlation to weather parameters}

The population of thrips was correlated with weather parameters viz. temperature, rainfall, relative humidity and sunshine hours. The correlation coefficient between flower thrips population and weather parameter revealed positive and highly significant with maximum temperature $(\mathrm{r}=0.705)$, minimum temperature $(\mathrm{r}=0.839)$ highly significant, positive and non significant with maximum $(\mathrm{r}=0.182)$, minimum $(r=0.565)$ relative humidity is positive and significant correlation and negatively non significant with rainfall $(\mathrm{r}=$ 0.390) while positive and non significant with sunshine $(\mathrm{r}=0.369)$ (Table 3). The present studies are corroborated with Patel et al., (2010) who reported that none of weather variables had significant impact on occurrence of thrips. Similarly Faleiro et al., (1990) also reported that relative humidity, bright sunshine hours and vapour pressure affect negatively; while, temperature and wind speed influenced positively on the population of thrips.

Seasonal activity of pod sucking bug ( $R$. dentipes)

Perusal of data presented (Tables 1 and 2; Fig. 2) on the incidence of pod sucking bug showed that the first appearance of pod 
sucking bug was started from $5^{\text {th }}$ week of September $\left(39^{\text {th }} \mathrm{SMW}\right)$. Initial population of pod sucking bug was 0.5 bugs per plant and reached to the maximum (9.0 bugs/plant) in the $2^{\text {nd }}$ week of November $\left(45^{\text {th }}\right.$ SMW). The pod sucking bug population was observed during the entire crop growth period with the prevalence of maximum $\left(32.5{ }^{0} \mathrm{C}\right)$ and minimum $\left(24.6{ }^{0} \mathrm{C}\right)$ temperature, morning $(92 \%)$ and evening $(57 \%)$ relative humidity and sunshine hours (7.2 hours/day) respectively. Thereafter, the population gradually decreased to 2.5 bugs/plant during the second week of December. The present findings are in agreement with Niba (2011) from South Africa; pod sucking bugs entered in cowpea fields at 8 weeks after sowing and remained on the crop till harvesting. They attained peak infestation level at 12 weeks after sowing.

\section{Correlation to weather parameters}

The mean jassid population was correlated with weather parameters viz. temperature, rainfall, and relative humidity and sunshine hours. The correlation coefficient between pod sucking bug population and weather parameter revealed negative and non significant with maximum temperature $(\mathrm{r}=$ 0.147), minimum temperature $(\mathrm{r}=-0.598)$ negatively significant (at $5 \%$ ), positively and non significant with maximum $(r=0.359)$, minimum ( $\mathrm{r}=-0.771)$ relative humidity is negative and highly significant (at $1 \%$ ) and negatively non significant with rainfall $(r=-$ 0.241 ) while positive and non significant with sunshine $(r=0.330)$.

\section{Seasonal activity of green stink bug (Nezara viridula)}

Periodical observations on the green stink bug incidence showed that the first appearance of green stink bug population was recorded from 5 th week of September ( $39^{\text {th }}$ SMW). Initially, the bugs population was 0.5 bugs per plant and it reached to maximum (12.3 bugs/plant) in the first week of November $\left(45^{\text {th }}\right.$ SMW). During this period, there was prevalence of maximum $\left(32.5^{\circ} \mathrm{C}\right)$ and minimum $\left(24.6{ }^{\circ} \mathrm{C}\right)$ temperature, morning (92\%) and evening $(57 \%)$ relative humidity and sunshine hours (7.2 hours/day), respectively. Thereafter, the population gradually declined to 4.5 bugs /plant during second week of December (Tables 1 and 2; Fig. 3).

\section{Correlation to weather parameters}

The mean population of green stink bug was correlated with weather parameters viz. temperature, rainfall, relative, humidity and sunshine hours. The correlation coefficient between green stink bug population and weather parameter revealed negative and non significant with maximum temperature $(\mathrm{r}=$ 0.194), minimum temperature $(\mathrm{r}=-0.520)$ negative and significant, positively and non significant with maximum $(\mathrm{r}=0.003)$, minimum $(r=-0.620)$ relative humidity is negatively significant and negatively non significant with rainfall $(\mathrm{r}=-0.316)$ while positive and non significant with sunshine $(r=$ 0.314) (Table 3).

\section{Seasonal activity of spotted pod borer (Maruca vitrata Fabricius)}

Periodical observations on the $M$. vitrata incidence showed that the first appearance of $M$. vitrata population was noticed from last week of September $\left(39^{\text {th }}\right.$ SMW). Initial incidence of $M$. vitrata was 10.6 per cent which reached to maximum (19.7 percent) in the third week of October ( $42^{\text {th }}$ SMW). During this period, there was prevalence of maximum $\left(32.5^{\circ} \mathrm{C}\right)$ and minimum $\left(24.6^{\circ} \mathrm{C}\right)$ temperature, morning $(92 \%)$ and evening relative humidity (57\%) and sunshine hours (7.2 hours/day), respectively. Thereafter, the population of $M$. vitrata was gradually declined (0.1/plant) during the last week of 
November ( $48^{\text {th }}$ SMW) (Tables 1 and 2; Fig. 4).

These finding are in conformity with Niba (2011) from South Africa, found that the larvae of this insect were invading the crop at four week after sowing (47th standard week). The peak level of infestation was observed at ten week after sowing (1st standard week) and disappeared at thirteen week after sowing (3rd standard week). Lalasangi, 1988also reported that the peak activity of $M$. vitrata has been observed during the month of July, August and October. Similarly Srivastava et al., 1992 reported two population peaks has been observed in moth catches from light traps at ICRISAT, Hyderabad i.e. first peak during September and second peak in early November to mid December, while it is between mid September to mid October at Hisar.

Table.1 Seasonal incidence of major insect pests on cowpea during Kharif, 2015-16

\begin{tabular}{ccccccc}
\hline SMW & $\begin{array}{c}\text { Flower } \\
\text { Thrips }\end{array}$ & $\begin{array}{c}\text { Pod } \\
\text { Sucking Bug }\end{array}$ & $\begin{array}{c}\text { Green } \\
\text { Stink Bug }\end{array}$ & $\begin{array}{c}\text { Spotted } \\
\text { Pod Borer } \\
\text { Infestation } \\
\text { Percent }\end{array}$ & $\begin{array}{c}\text { Lady } \\
\text { Bird } \\
\text { Beetle }\end{array}$ & Spider \\
\hline 39 & 3.1 & 0.5 & 0.5 & 10.6 & 0.2 & 0.9 \\
40 & 4.3 & 3.5 & 9.3 & 16.7 & 0.3 & 0.4 \\
41 & 2.8 & 4.3 & 5.0 & 13.6 & 0.5 & 1.0 \\
42 & 3.0 & 3.3 & 8.3 & 19.7 & 0.6 & 1.4 \\
43 & 2.4 & 3.5 & 5.8 & 14.4 & 0.5 & 1.2 \\
44 & 2.3 & 1.5 & 8.0 & 12.1 & 0.2 & 1.6 \\
45 & 2.1 & 9.0 & 12.3 & 12.1 & 0.8 & 0.8 \\
46 & 1.7 & 7.8 & 10.5 & 12.1 & 0.8 & 1.0 \\
47 & 2.1 & 8.8 & 9.0 & 9.1 & 1.3 & 1.4 \\
48 & 2.4 & 6.8 & 7.3 & 15.2 & 1.5 & 1.4 \\
49 & 1.8 & 4.5 & 12.3 & 12.1 & 1.0 & 1.2 \\
50 & 1.5 & 2.5 & 4.3 & 15.2 & 0.8 & 1.0 \\
\hline Seasonal mean & $\mathbf{2 . 4}$ & $\mathbf{4 . 6}$ & $\mathbf{7 . 7}$ & $\mathbf{1 3 . 6}$ & $\mathbf{0 . 7}$ & $\mathbf{1 . 1}$ \\
\hline
\end{tabular}

Table.2 Period of activity and population of major insect pests of cowpea crop during Kharif 2015-16

S.N. Common name

1. $\quad$ Flower thrips

2. Pod sucking bug

3. Green stink bug

4. $\quad$ Spotted pod borer
Range of incidence

$1.5-4.3$

$0.5-9.0$

$0.5-12.3$

9.1-19.7
Status of peak activity

First week of October

Second week of November

Second week of November

Third week of October 
Table.3 Correlation between major insect pests of cowpea and weather parameters

\begin{tabular}{|c|c|c|c|c|c|c|}
\hline \multirow{2}{*}{$\begin{array}{l}\text { Mean } \\
\text { population/ } \\
\text { per cent } \\
\text { infestation per } \\
\text { plant }\end{array}$} & \multicolumn{2}{|c|}{ Temperature $\left({ }^{\circ} \mathbf{C}\right)$} & \multicolumn{2}{|c|}{$\begin{array}{l}\text { Relative humidity } \\
(\%)\end{array}$} & \multirow{2}{*}{$\begin{array}{l}\text { Rainfall } \\
(\mathbf{m m})\end{array}$} & \multirow{2}{*}{$\begin{array}{l}\text { Sunshine } \\
\text { (hrs) }\end{array}$} \\
\hline & Max. & Min. & Max. & Min. & & \\
\hline Flower thrips & $0.705^{* *}$ & $0.839 * *$ & 0.182 & $0.565^{*}$ & -0.390 & 0.369 \\
\hline Pod sucking bug & -0.147 & $-0.598^{*}$ & 0.359 & $-0.771 * *$ & -0.241 & 0.330 \\
\hline Green stink bug & -0.194 & $-0.520 *$ & 0.003 & $-0.620 *$ & -0.316 & 0.314 \\
\hline Pod borer & 0.490 & 0.405 & 0.152 & 0.127 & 0.178 & 0.023 \\
\hline
\end{tabular}

Table.4 Correlation coefficient between population of natural enemies and insect pests of cowpea during Kharif season 2015-16

\begin{tabular}{ccccc}
\hline Natural enemies & $\begin{array}{c}\text { Flower } \\
\text { thrips }\end{array}$ & $\begin{array}{c}\text { Pod sucking } \\
\text { bug }\end{array}$ & $\begin{array}{c}\text { Green stink } \\
\text { bug }\end{array}$ & $\begin{array}{c}\text { Spotted pod } \\
\text { borer }\end{array}$ \\
\hline Lady bird beetle & -0.501 & - & - & -0.136 \\
Spider & - & 0.001 & 0.013 & -0.095 \\
\hline
\end{tabular}

Fig.1 Average number of flower thrips (Megalothrips sjoestdi) on cowpea crop as influenced by different weather parameters during kharif, 2015

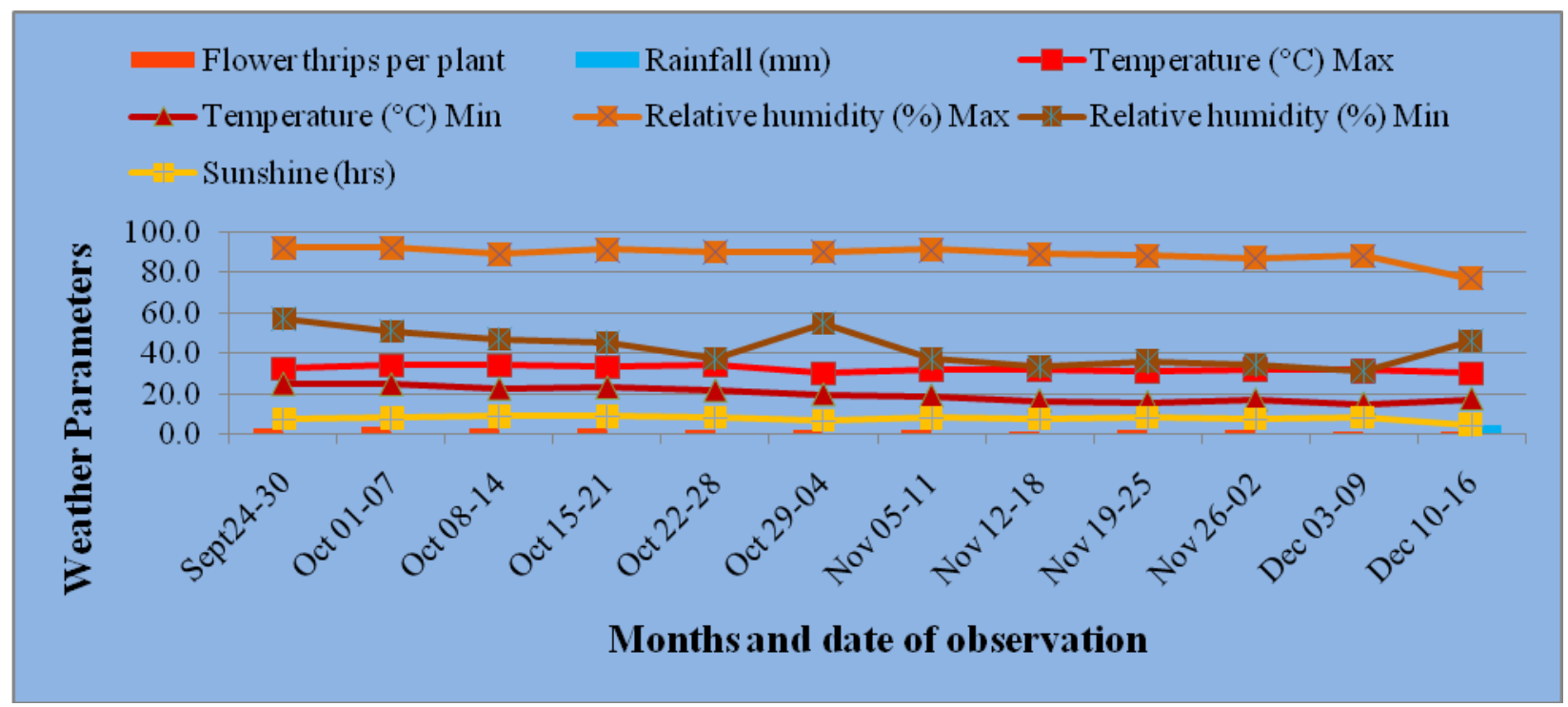


Fig.2 Average number of pod sucking bug (Riptorsus dentipes) on cowpea crop as influenced by different weather parameters during kharif, 2015

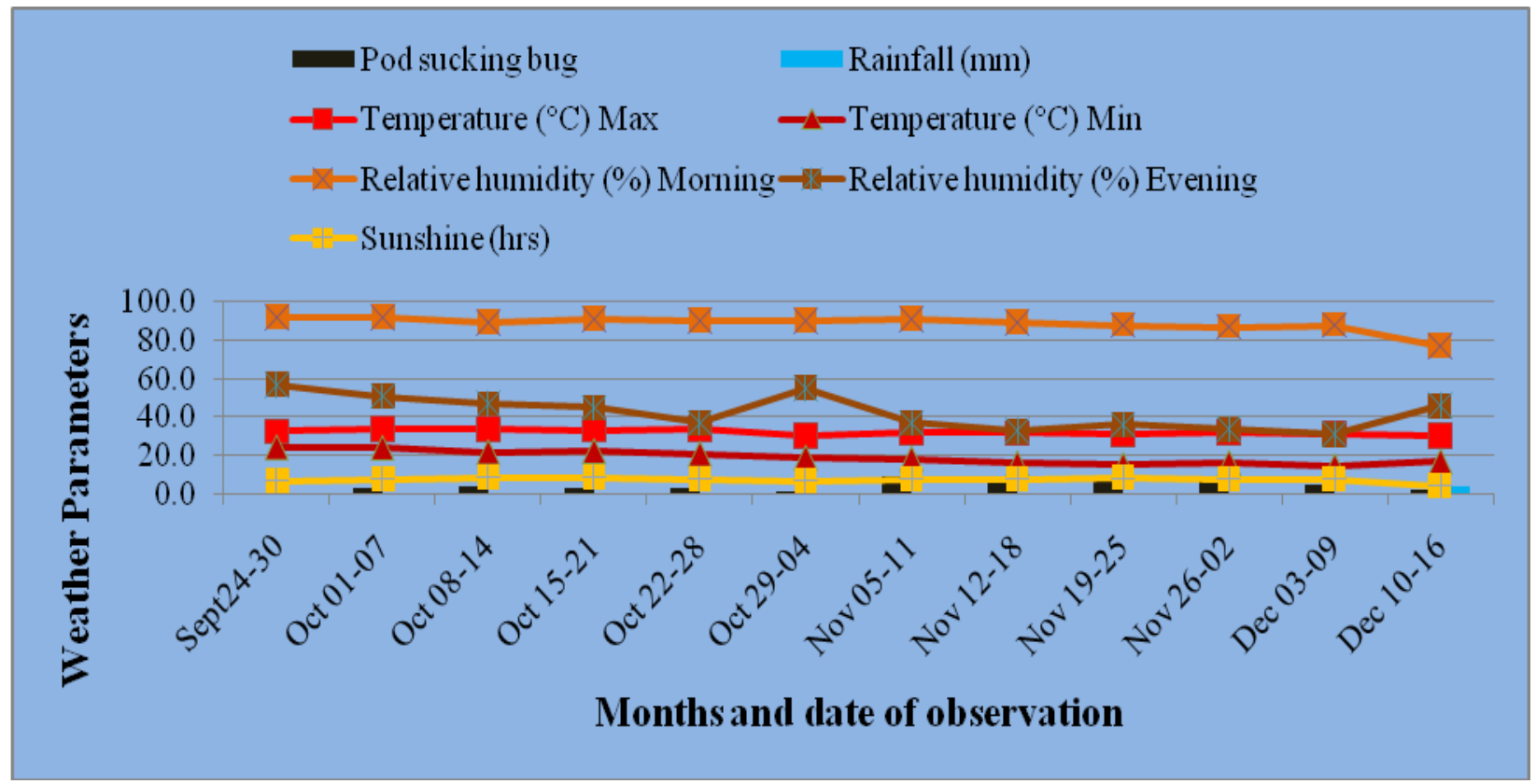

Fig.3 Average number of green stink bug (Nezara viridula) on cowpea crop as influenced by different weather parameters during kharif, 2015

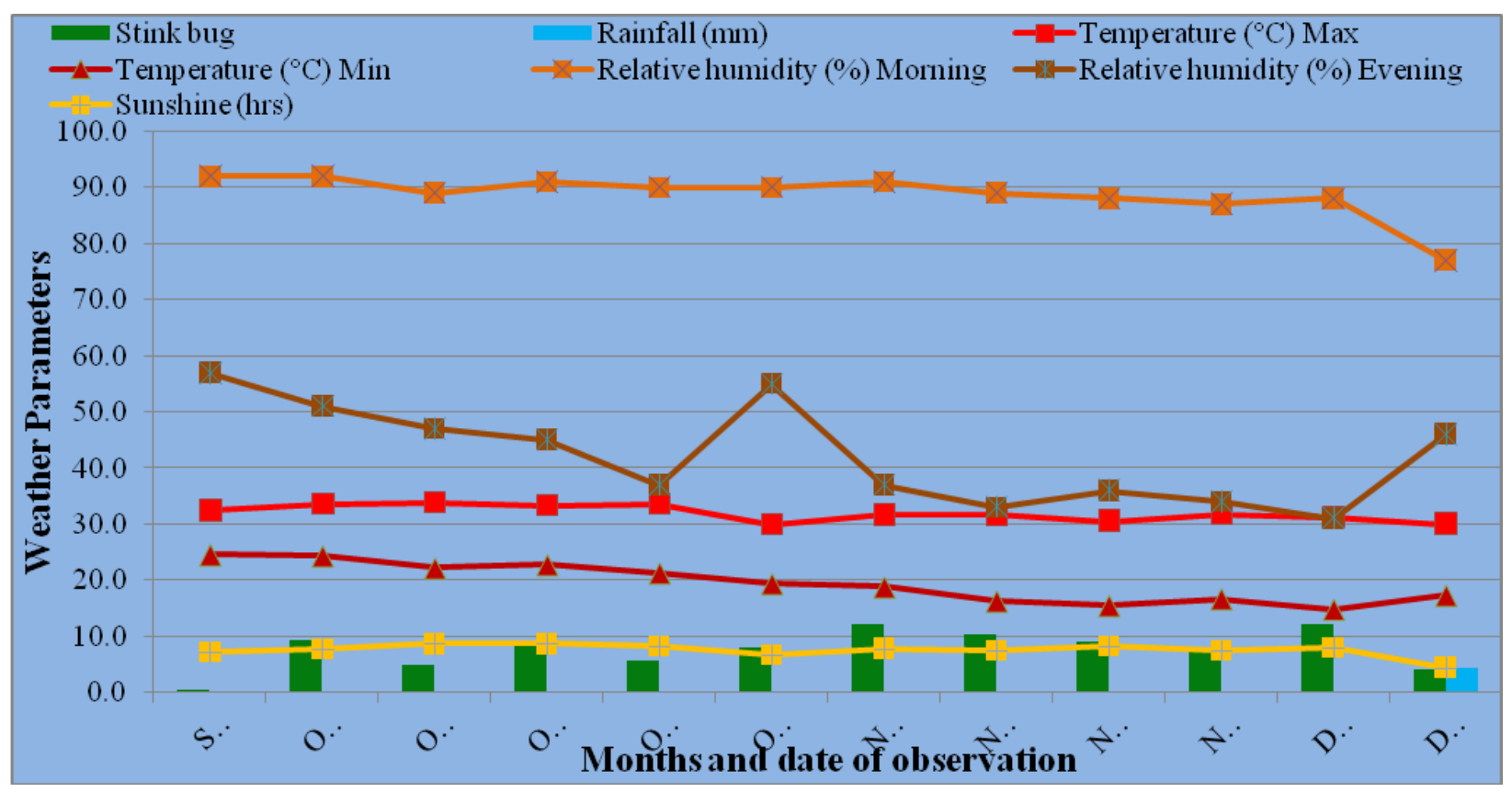


Fig.4 Pod borer infestation (Maruca vitrata) on cowpea as influenced by different weather parameters during kharif, 2015

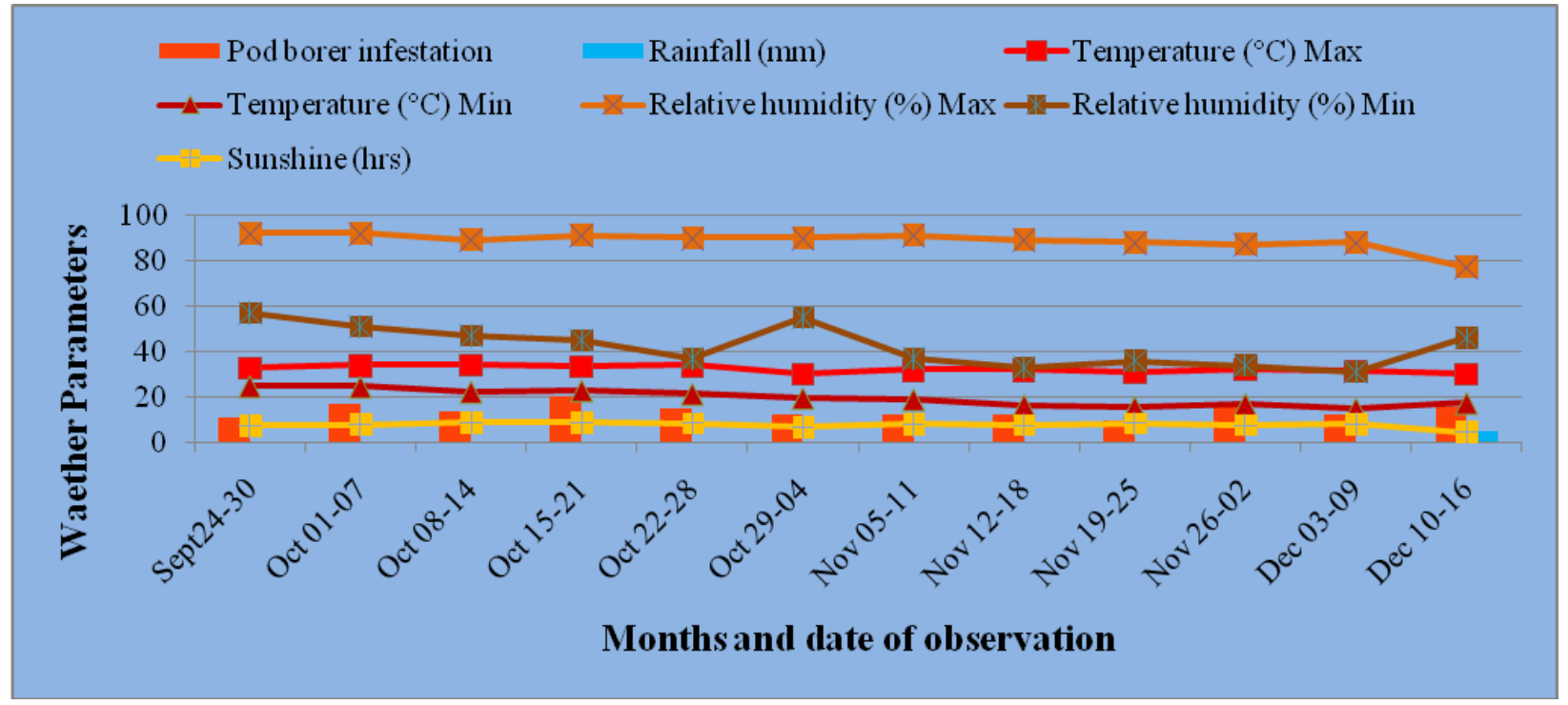

\section{Correlation to weather parameters}

The mean population of $M$. vitrata was correlated with weather parameters viz. temperature, rainfall and relative humidity and sunshine hours. The correlation coefficient between spotted pod borer infestation and weather parameter revealed positive and non significant with maximum temperature $\quad(\mathrm{r}=\quad-0.490), \quad$ minimum temperature $(\mathrm{r}=0.405)$, maximum $(\mathrm{r}=0.152)$, minimum $(\mathrm{r}=-0.127)$ relative humidity, rainfall $(\mathrm{r}=0.178)$ and sunshine $(\mathrm{r}=0.023)$ (Table 3).

\section{Correlation co-efficient between major insect pest of cowpea and biotic parameters}

Perusal of data presented (Table 4) revealed that the flower thrips population showed negatively non significant correlation to lady bird beetle $(\mathrm{r}=-0.501)$, spotted pod borer infestation also showed that negatively non significant correlation to lady bird beetle ( $\mathrm{r}=-$ $0.140)$ and spider $(r=-0.095)$. The pod sucking bug and green stink bug population showed non-significant positive correlation with natural enemies.

\section{References}

Adati, T., Tamò, M., Yusuf, S.R., Downham, M.C.A., Singh, B.B. and Hammond W. 2007. Integrated pest management for cowpea-cereal cropping systems in the West African savannah, Int. J. Trop. Insect Sci., 27: 123-137.

Faleiro, J.R., Singh, K.M. and Singh, R.N. 1990. Influence of abiotic factors on population build up of important insect pests of cowpea, Vigna unguiculata (L) Walp. and their biotic agents recorded at Delhi. Indian J. Entomol., 52: 75680.

Gomez, K.A. and Gomez, A.A. 1984. Statistical procedures for agricultural research, John Wiley \& Sons.

Jackai, L.E. 1982. A field screening technique for resistance of cowpea (Vigna unguiculata) to the pod-borer Maruca testulalis (Geyer) (Lepidoptera: Pyralidae). Bull. Entomol. Res., 72(01): 145-156.

Kumar, A. and Kumar, A. 2015. Effect of abiotic and biotic factors on incidence 
of pests and predator in cowpea [Vigna unguiculata (L.) Walp.]. Legume Res. An Int. J., 38(1): 121-125.

Lalasangi, M.S. 1988. Bionomics, loss estimation and control of pod borer, Marucates tulalis Gey. (Lepidoptera: Pyralidae) on cowpea. Mysore J. Agric. Sci., 22: 187-188.

Niba, A.S. 2011. Arthropod assemblage dynamics on cowpea, Vigna unguiculata (L) Walp. in subtropical agroecosystem, South Africa. African $J$. Agril. Res., 6: 1009-1015.

Patel, S.K., Patel, B.H., Korat, D.M. and Dabhi, M.R. 2010. Seasonal incidence of major insect pests of cowpea, Vigna unguiculata (Linn.) Walpers in relation to weather parameters. Karnataka $J$. Agril. Sci., 23: 497-499.

Singh, B.B., Mohan D.R., Raj D.R., Dashiell K.E. and Jackai L.E.N. 1997. Advances in cowpea research. Co-publication of International Institute of Tropical Agriculture (IITA) and Japan International Research centre for Agricultural science (JIRCAS), IITA, Ibadan, Nigeria.

Singh, C. and Singh, N.N. 2014. Occurrence of insect-pests infesting cowpea (Vigna unguiculata walpers) and their natural enemy complex in associations with weather variables. Legume Res. An Int. J., 37(6): 658-664.

Srivastava, C.P., Pimbert, M.P. and Jadhav, D.R. 1992. Monitoring of adult population of Murucates tulalis (Geyer) with light traps at Patancheru and Hisar in India. Pigeonpea Newslett., 15: 27-28

Uwaegbute, A.C. 1991. Weaning practices and weaning foods of the Hausas, Yorubas and Ibos of Nigeria. Ecol. Food and Nutrition, 26: 139-153.

\section{How to cite this article:}

Maya Shree Mahipal, Shri Gajendra Chandrakar, Yashpal Singh Nirala, Devendra Nishad and Birendra Tigga. 2017. Seasonal Incidence of Major Insect Pests of Cowpea in Relation to Biotic and Abiotic Factors. Int.J.Curr.Microbiol.App.Sci. 6(8): 1777-1784.

doi: https://doi.org/10.20546/ijcmas.2017.608.210 